\title{
"TAKING ALL HINTS TO USE THEM": The Sources of "Out of the Cradle Endlessly Rocking"
}

\author{
Michael VANDE BERG
}

A CONSIDERABLE NUMBER of source studies have demonstrated Whitman's indebtedness to a literary tradition he went to great lengths to disclaim. Fifty years ago Richard Harrison noted that "a compilation of [the reasonably pertinent] relationships of one kind and another which have been suggested as existing between Whitman's writings and the writings of others, would reach astounding proportions." Some thirty years ago Esther Shephard concluded that "Whitman's method of appropriating another's ideas as his own, is unparalleled, so far as far as I know, in the story of literary borrowings." More recently Milton Hindus, after identifying echoes of Shakespeare, Tennyson, and The Song of Songs within "Passage to India," called Whitman's poetry "a treasure trove of barely hidden allusions and literary references." 1 The terms chosen by these critics to express the magnitude of Whitman's literary indebtedness - relationships between his and others' works of "astounding proportions," appropriations "unparalleled in the story of literary borrowings," "a treasure trove" of allusions and references - are particularly relevant when applied to "Out of the Cradle Endlessly Rocking," a poem which contains an astonishing number of echoes of, and allusions to, the works of other authors. Several of these echoes and allusions have been individually identified in earlier studies: for instance, at least three critics-Hindus, Ned Davison, and Joseph DeFalco-have noted the striking echoes from Poe's "The Raven" in "Out of the Cradle"; 2 Thomas Brasher has suggested Emma Willard's "Rocked in the Cradle of the Deep" as a source of the poem's opening line; ${ }^{3}$ two critics have independently identified J. P. Giraud's Birds of Long Island as the source of most of the descriptive details of the mockingbird in the poem (as well as the source of Whitman's knowledge of the awk, heron, and nighthawk in other poems); ${ }^{4}$ and Shephard has suggested another prose work, Heine's Pictures of Travel, as the source of many of the poem's phrases and images. ${ }^{5}$ However, while this is in itself an impressive array of sources for a single poem, the list is far from complete: for the basic material of "Out of the Cradle" can also be traced to several Tennyson poems, to Byron, Coleridge, Shelley, Blake, Shakespeare, The Old Testament, and even to articles of literary criticism that Whitman is known to have had in his possession. The identification both of so many source works and of the pattern that these sources assume within "Out of the Cradle" helps shed new light on the allegorical nature of the poem, and on Whitman's creative imagination in general. 
The major obstacle to identifying sources in Whitman's poetry has traditionally been his reputation as the "original American poet," a reputation Whitman himself carefully nurtured into being, especially during the early years of his career. His relationship to Tennyson, for instance, was long considered within the general context of his denials of indebtedness, and especially within the context of his well-known remark that Tennyson was "the bard of music and of the aristocracy."6 However, in recent years, thanks in large part to Herbert Bergman's careful study of the relationship between Whitman and Tennyson, we have become more receptive to the notion that the English poet significantly influenced Whitman. Among other things, Bergman established that Whitman was a close follower of Tennyson's poetry, that he made frequent comments on his artistry, that he collected and scored many critical articles about Tennyson, that he himself wrote several articles about Tennyson's poetry-including an anonymous 1855 review of Leaves of Grass, "An English and an American Poet," in which he compared Tennyson's poetry with the first edition of his own poems - and that he was the initiator of their correspondence, which continued from 1871 until Whitman's death. In spite of reservations about individual poems, Whitman "placed Tennyson, [whom he called] 'the greatest living poet,' among the great masters, admired him, and considered him his favorite poet."7 Thus it is perhaps not so surprising that there should be several echoes of Tennyson poems in "Out of the Cradle." Line 128, for instance, clearly echoes a line from Tennyson's In Memoriam: ${ }^{8}$

Whitman:

But my mate no more, no more with me!

Tennyson:

That I shall be thy mate no more. (XLI)

Within the mockingbird's first song after losing his mate sound the unmistakable echoes of another Tennyson poem, the beautiful second Song from "The Princess": 9

\section{Whitman:}

Blow! blow! blow!

Blow up sea-winds along Paumanok's shore;

I wait and I wait till you blow my mate to me. (1l. 52-54)

\section{Tennyson:}

Sweet and low, sweet and low,

Wind of the western sea,

Low, low, breathe and blow,

Wind of the western sea!

Over the rolling waters go,

Come from the dying moon, and blow,

Blow him again to me. [my italics] 
The words, the dramatic situation, the mood, the setting with the wind blowing on the sea, the plea to return the lost mate: all are captured in Whitman's three-line synopsis.

Other echoes from "The Princess" Songs appear in "Out of the Cradle" as well: for instance, Whitman's image of the rocked cradle in the poem's opening line, which in the first (1860) printing appeared as

Out of the rocked cradle,

echoes an image from the fifth Song of "The Princess":

And lay me on her bosom and her heart

Would rock the snowy cradle till I died. [my italics]

That Tennyson's poem is a source of "Out of the Cradle's" opening line is further suggested by the fact that the image at the end of Whitman's poem echoes another image from one of "The Princess" Songs:

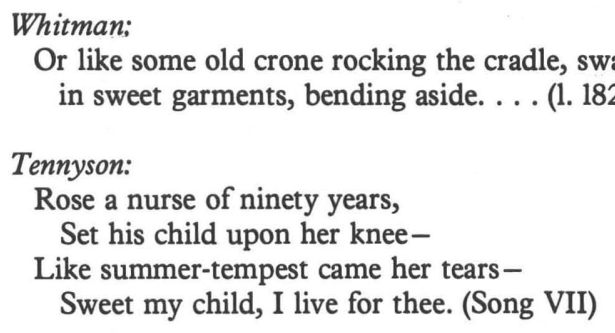

Here Whitman's "rocking cradle" again echoes the fifth "Princess" Song, while his "old crone" finds a source in Tennyson's ninety-year-old nurse of the seventh Song. And while the phrase "sweet garments" echoes Tennyson's use of the word "sweet" in both Songs, an intriguing bit of external evidence makes it tempting to further regard Whitman's choice of the word in this context - within a poem echoing several Tennyson poems, and within a passage specifically echoing two of those poems - as a veiled allusion to his indebtedness to Tennyson. For Whitman on several occasions used this word "sweet" to characterize Tennyson's poetry: in his article "Poetry To-Day in America," for instance, he wrote that Tennyson's poetry was written to "an extreme of sweetness"; within a critical article he owned, "Recollections of Poets Laureate," he wrote in a margin that "Maud" had "some sweet passages"; and in the same article he twice marginally scored the line, "[Tennyson's] strength lies in his sweetness." 10 These characterizations of Tennyson's poetry as "sweet" suggest that in "Out of the Cradle" Whitman is privately acknowledging Tennyson's role in providing him with several images in the poem-in particular with the image of the "old crone" who is 
"swathed in" the "sweet garments" of Tennyson's sad-sweet "Princess" Songs.

The poem contains several other examples of such figurative word play, apparent attempts by Whitman to thinly disguise his borrowings either, as above with the word "sweet," by alluding to a source poet or poem through private symbols, or by slightly altering - at times in an almost playful manner-the language or imagery of the orignal source. For instance, in these lines from the poem, where the mockingbird looks out toward the sea while mourning the death of his mate:

\author{
Shake out carols! \\ Solitary here, the night's carols! \\ Carols of lonesome love! death's carols! \\ Carols under that lagging, yellow, waning moon! (11. 99-102)
}

Whitman's use of the word "carol," the mournful tone, the setting on the shore, and the presence of a character facing out to sea bewailing the loss of a loved one suggest a source in Tennyson's "Morte D'Arthur"11 at the point where Sir Bedivere mournfully watches the dying Arthur float out to sea on his death barge:

... the barge with oar and sail

Moved from the brink, like some full-breasted swan

That, fluting a wild carol ere her death,

Ruffles her pure cold plume, and takes the flood. . . . (11. 433-436)

In addition to the parallels in tone, diction, and setting, Whitman's phrase "Shake out carols" especially suggests his use of Tennyson's passage since the term "shake out" in its nautical sense (in nineteenth-century usage) means "to unfasten or unfurl and let out" a sail. ${ }^{12}$ Tennyson figuratively describes the unfurling of the sail of Arthur's boat through the simile of the swan ruffling its plume; Whitman in borrowing from the passage uses the literal term "shake out" rather than Tennyson's figurative equivalent, apparently in order to disguise his indebtedness. Significantly, Whitman used the term "shake out" in precisely this nautical sense in two other poems, "A Boston Ballad" and "Passage to India."

Echoes of Byron's Childe Harold's Pilgrimage appear in the fourth line of Whitman's poem:

Over the sterile sands and the fields beyond, where the child leaving his bed wander'd alone, bareheaded, barefoot. . . .

This line is an effective "paraphrased quote" of a lengthy single passage from the Third Canto of Byron's Poem: 
In my youth's summer I did sing of One,

The wandering outlaw of his own dark mind;

Again I seize the theme, then but begun,

And bear it with me, as the rushing wind

Bears the cloud onwards: in that Tale I find

the furrows of long thought, and dried-up tears,

Which, ebbing, leave a sterile track behind,

O'er which all heavily the journeying years

Plod the last sands of life-where not a flower appears. (III)

Whitman seems even to have (cleverly or embarrassingly) employed the word "Childe" from the title of Byron's poem; whether he knew the actual meaning of the word is unimportant -it served his purpose. The probability that six "content" words or their equivalents - "youth," "One," "wandering," "sterile," "O'er," and "sands" - from one stanza of a poem might randomly occur in a single line of another poem is mathematically unlikely, to say the least. The further chance that the line would be a reasonable paraphrase of the stanza, as is the case here, is even more remote. ${ }^{13}$

There is at least one echo of Byron's "The Prisoner of Chillon" in Whitman's poem as well:

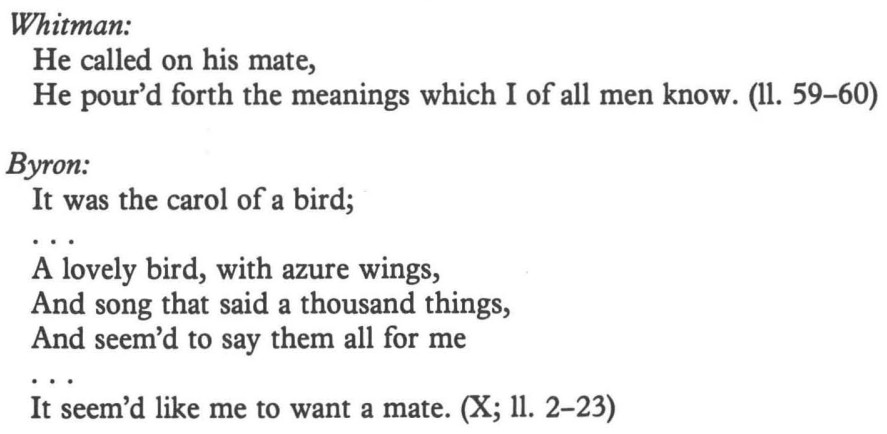

Whitman's image of the solitary bird, who in calling for its mate conveys a message that only the poet understands, especially suggests Byron's poem as a source.

The fifth line of Whitman's poem - "Down from the shower'd halo"echoes images from Shelley's "To a Skylark."14 The echoes are particularly clear when a line from Shelley's poem is compared with the first line from "Out of the Cradle" as it appeared in the original (1860) edition:

\section{Whitman:}

Down from the showered halo and the moonbeams. ...

Shelley:

The moon rains out her beams - and Heaven is overflowed. (1. 30) 
Whitman's "showered halo" also apparently paraphrases and combines the "rainbow" and "showers" of these lines from Shelley's poem:

From rainbow clouds there flow not

Drops so bright to see

As from thy presence showers a rain of melody. . . . (11. 33-35)

And these familiar lines from Whitman's poem,

Demon or bird! (said the boy's soul,)

Is it indeed toward your mate you sing? or is it really

to me? (11. 144-145)

echo Shelley's

Teach us Sprite or Bird,

What sweet thoughts are thine. (11. 61-62)

The joyful, frenetic quality of the bird's first song in Whitman's poem (sung before he has lost his mate) suggests a source in the enthusiastic exclamations of The Song of Songs:

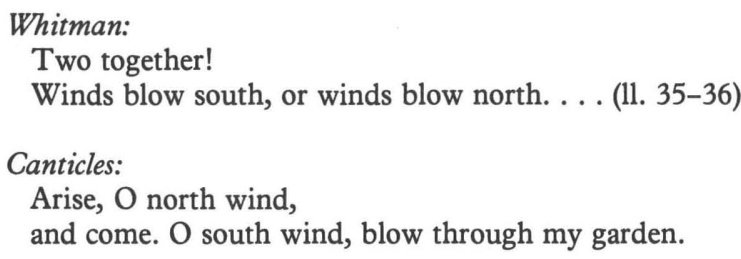

Several lines from Job are echoed in Whitman's poem as well:

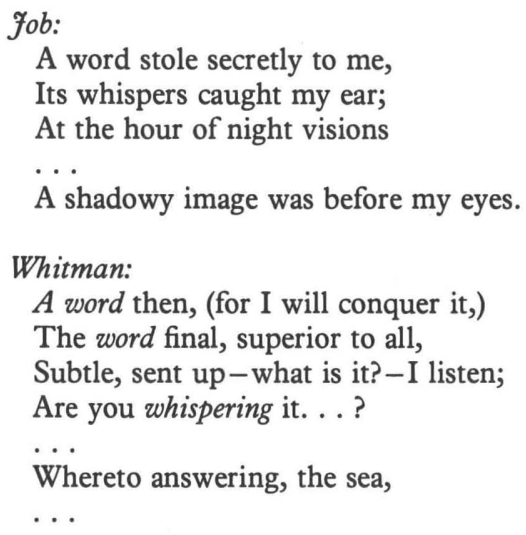


Whisper'd me through the night, and very plainly before daybreak,

Lisp'd to me the low and delicious word death. . . . (11. 160-167; my italics)

While the prescence of the "shadowy image" is terrifying to Job, for Whitman the presence of the word "death" is soothing: once again, Whitman has adapted an image for his own purposes, while preserving much of its original character - in this case, the "shadowy image" is preserved as "death," as are the word/images "A word," "whispers," and "hour of night," the last image symbolizing in both works a time of despair.

The presence of Biblical echoes in a Whitman poem is not surprising, of course: numerous studies have pointed out Biblical echoes and paraphrases in many of Whitman's poems. In fact, Hindus has pointed out echoes of The Song of Songs within "Passage to India," while Gay Wilson Allen has identified echoes from both The Song of Songs and Job in other Whitman works. ${ }^{15}$ However, it is possible that the direct source of $11.160-167$ in the poem is not the text of Job itself, but rather an 1849 critical article that Whitman is known to have read, "Christopher Under Canvas," in which appears the above-quoted passage from Job. This article, one of four critical pieces discussing Wordsworth's The Prelude that Whitman is known to have had in his possession, seems to have made quite an impression on him: it is heavily annotated, and one passage which Whitman has marked with a hand-drawn pointing finger is clearly echoed in Whitman's 1870 description of Leaves of Grass:

\section{"Christopher Under Canvas":}

A discourse in verse resembles a billowy sea. The verses are the waves that rise and fall-to our apprehension-each by impulse, life, will of its own. All is free. [article's italics] ${ }^{16}$

\section{Whitman:}

Its analogy is the Ocean. Its verses are the liquid, billowy waves, ever rising and falling ... never having the sense of something finished and fixed. [my italics] ${ }^{17}$

\section{Lines 168-169 of Whitman's poem,}

Lisp'd to me the low and delicious word death,

And again death, death, death, death, ... .

echo passages from two Shakespeare plays. ${ }^{18} \mathrm{~A}$ line from King $\mathfrak{f o h n}$,

Death, death: $O$, amiable lovely death! (III. iv. 25)

is evidently the source of line 168; that this is the source is further suggested by Bartlett's identification of "amiable lovely death" as the apparent source of a similar "death line" in the elegiac "When Lilacs Last in the Dooryard 
Bloom'd,"19 which, like the line in "Out of the Cradle," employs two (serene) adjectives as modifiers of the word "death":

Come lovely and soothing death. . . . (1. 135)

The four consecutive repetitions of the word "death" in line 169 of "Out of the Cradle" suggest a source in Lear's death speech in the fifth act of King Lear:

Thoul't come no more,

Never, never, never, never, never. (V. iii. 309-310)

Echoes from several Coleridge works also appear in "Out of the Cradle." For instance, Whitman's act of "fusing" the bird's song, his own song, and the word from the sea strikingly recalls Coleridge's description in Biographia Literaria $^{20}$ of the "ideal poet's imaginative act of fusion":

\author{
Whitman: \\ But fuse the song of my dusky demon and brother, \\ With the thousand responsive songs at random, \\ My own songs awaked from that hour, \\ And with them the key, the word up from the waves. . . (11. 175-179)
}

\title{
Coleridge:
}

He diffuses a tone and spirit of unity that blends and (as it were) fuses, each into each, by that synthetic and magical power to which we have exclusively appropriated the name of imagination. (Ch. XIV; Coleridge's italics)

Coleridge's further influence can be detected in this line from Whitman's poem:

\section{O night! do I not see my love fluttering out among the breakers? (1. 79)}

This line is a figurative adaptation of a passage from Coleridge's "Frost at Midnight":

How oft, at school, with most believing mind, Presageful, have I gazed upon the bars,

To watch that fluttering stranger! (11. 24-26)

The dramatic situation is the same at this point in both poems: both depict a central character anticipating the arrival of a loved one. Whitman's mockingbird looks out toward the "breakers," while the boy in Coleridge's poem "gazes upon the bars" of the fire-place grate. Whitman has adapted 
Coleridge's fire-place setting to his own setting on the sea-shore by replacing Coleridge's "Bars" with the word "breakers," a word nearly synonymous with "bars" in one sense - waves becoming "breakers" at the point where they meet "the bars." That Whitman made this association between the two words is suggested by his familiarity with the meaning of "bar" as a "horizon line" or "sand bar," indicated by his use of "bar" in "There Was a Child Went Forth" - the only time he used the word in his poetry:

The strata of color'd clouds, the long bar of maroon-tint away solitary by itself, the spread of purity it lies motionless in. . . . [my italics]

His substitution, within the context of the bird's anticipation of its mate, of "my love fluttering" for Coleridge's "fluttering stranger" also indicates that he was familiar with a bit of nineteenth-century folk-lore which appeared in Coleridge's own note accompanying most editions of the poem: "In all parts of the kingdom these films [on the fire-place grate] are called strangers and supposed to portend the arrival of some absent friend."21

Echoes of Coleridge's "Rime of the Ancient Mariner" appear in "Out of the Cradle" almost immediately after the echoes of "Frost at Midnight"; between the two passages which echo these Coleridge poems appears this single line:

What is that little black thing I see there in the white? (1. 80)

The line clearly echoes the first line of a passage from Blake's "The Chimney Sweeper":

A little black thing among the snow

Crying “'weep, 'weep," in notes of woe! (11. 1-2; my italics)22

Whitman's use of the term "little black thing" is striking; the image of "black" on white" is the same; and the lisping cry of Blake's little boy closely resembles the cry of a bird. That this single-line borrowing from Blake's poem should appear between passages echoing two Coleridge poems is itself significant: for the line from Blake seems to have been suggested to Whitman by an image from "Rime of the Ancient Mariner":

When looking westward, I beheld

A something in the sky.

At first it seemed a little speck,

And then it seemed a mist;

It moved and moved, and took at last

A certain shape, I wist.

A speck, a mist, a shape, I wist. (11. 147-153) 
The mariner is unable to determine what it is that he sees on the horizon; this would appear to be the reason Whitman has chosen to use Blake's undistinguishing words, "little black thing," in his own line. Further echoes from "Rime of the Ancient Mariner" within "Out of the Cradle" also suggest that Whitman did have Coleridge's poem in mind when he borrowed Blake's phrase. For instance, the repetition of the word "shape" in the last two of the above-quoted lines from Coleridge's poem is echoed inthis line of "Out of the Cradle":

$O$ it is the shape, the shape of my mate! (1. 88)

The exclamatory quality of the bird's cry in Whitman's poem when he believes he has seen his mate recalls the mariner's own exclamation when he realizes that it is a sail he sees out across the water:

\section{Whitman:}

Loud! loud! loud!

Loud I call to you, my love!

High and clear I shoot my voice over the waves. . . (11. 81-83)

Coleridge:

I bit my arm. . .

And cried, a sail! a sail! (11. 160-161)

The image in Whitman's poem of the moon almost touching the ocean, with the "dusky spot" in the moon's "brown yellow," echoes the image in Coleridge's poem of the low-lying sun with the "strange shape" placed before it:

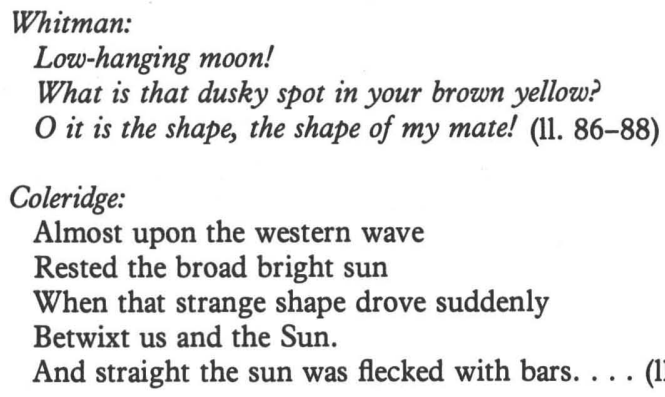

And again the bird's exclamatory cry in Whitman's poem recalls the Mariner's cry when he finally sights land:

\section{Whitman:}

Land! land! O land! (1. 90) 


\section{Coleridge:}

$\mathrm{Oh}$ ! dreams of joy! is this indeed

The lighthouse top I see?

Is this the hill? is this the kirk?

Is this mine own countree? (11. 464-467)

The presence of these many echoes and barely disguised allusions in "Out of the Cradle" raises the obvious question as to whether Whitman borrowed consciously or unconsciously in the poem. Whitman studies have traditionally proceeded on the assumption that any evidenced borrowing was probably unintentional and unconscious; however, where "Out of the Cradle" is concerned, a good case can be made that Whitman consciously used the materials of other writers. Several earlier studies have determined that Whitman did indeed consciously borrow material for use in several of his poems (including "Out of the Cradle"); ${ }^{23}$ however, the present conclusion about Whitman's conscious use of source material is based not only on such previous studies, nor even on the number and pattern of the echoes and allusions in the poem, but on other, and equally compelling evidence. There is, for instance, Whitman's private written intention to write a poem "bringing together the materials" from other poems:

The Poem. One grand eclipsing Poem. Poem of Materials. ?Several Poems. ?Many poems on this model - the bringing together of the materials - words, figures, suggestions, things -(words as solid as timbers, stone, iron, brick, glass, planks etc.) All with reference to main central ideas. With powerful indications - yet loose, fluid-like, leaving each reader eligible to form the resultant-poem for herself or himself. Leading Chicago poem. [Whitman's italics] ${ }^{24}$

No critic has yet identified this "Poem of Materials"; and the identification of "Several Poems" within the text of "Out of the Cradle" argues that it is the "resultant-poem," or perhaps one of "many poems" that grew out of this plan. "Out of the Cradle" is indeed "loose and fluid-like" and the great variety of critical readings that the poem has prompted suggests that Whitman succeeded in writing a poem that "left each reader eligible to form the resultantpoem for herself or himself." However, it is Whitman's stated intention to "bring together the materials ... all with reference to main central ideas" that most strongly suggests "Out of the Cradle" as one of the "resultant poems"; for the great majority of works that are the "materials" of Whitman's poem share at least one of two basic themes, or "main central ideas": they depict either the growth of an individual or despair at the loss of a loved one. Childe Harold's Pilgrimage and "Rime of the Ancient Mariner" are essentially spiritual autobiographies; In Memoriam is an elegy, as is the book of Job (it moves from Job's despair at his losses to his sense of renewed hope); "The Prisoner of Chillon," the Songs from "The Princess," "The Raven," "The Chimney Sweeper," King Lear, and even the Song of Songs contain elegiac elements.

This convergence of source materials around two "main central ideas," 
or themes, is especially significant within the context of Harrison Morris's description (among others) of Whitman's method of composition:

He said an idea would strike him which, after mature thought, he would consider fit to be the "special theme" of a "piece." This he would revolve in his mind in all its phases, and finally adopt, setting it down crudely on a bit of paper ... which he would place in an envelope. Then he would lie in wait for any other material which might bear or lean toward that idea, and, as it came into his mind, he would put it on paper and place it in the same envelope. After he had quite exhausted the supply of suggesions ... he would interweave them in a "piece," as he called it. I asked him about the arrangement or succession of the slips, and he said, "They always fall properly into place." [my italics] ${ }^{25}$

A precise description of what a "piece" looked like after he had "interwoven" the slips and they had "fallen into place" is provided by William Garrison's reminiscence:

I have seen a manuscript, a part of "November Boughs," a single page of which was composed of at least a dozen kinds of paper, written in black pencil, blue pencil, black ink, and red ink ... and each piece of a different size, shape, and color. ${ }^{26}$

These descriptions help to provide a possible means of explaining both the composite borrowings and the sheer number of borrowings in "Out of the Cradle." Once Whitman hit upon the idea of a theme or, perhaps, of a single central image of a poem he "lay in wait for material," apparently either by calling up lines and images from others' poems and articles out of what seems to have been a prodigious memory, or, pursuing it more directly, by copying and altering lines from books and articles - a process which would have been considerably convenienced by his habit of tearing or clipping out poems and articles from anthologies and magazines. The scraps of paper containing the remembered and copied lines were then laid out and organized, with the very similar source-borrowings juxtaposed, and in some cases "fused," into a single line or image of the poem.

The possible autobiographical basis of "Out of the Cradle" has often been discussed. Allen notes that "nearly all critics have thought it a veiled allegory of a personal experience," but that other than Whitman's hint that the poem is "founded on a real incident," he "gave no clues ... to [its] possible origin." ${ }^{27}$ However, Whitman did leave a variety of clues within the poem: first, within the barely disguised echoes and allusions which, when identified, reveal the fact that most of the source works of the poem are spiritual autobiographies and elegies; and second, within the poem's private symbols which, when traced to their sources, reveal the allegorical nature of the poem. Together these clues indicate that "Out of the Cradle" is Whitman's allegorical re-creation of his genesis as a poet, a spiritual autobiography with an elegiac structure and resolution written in the tradition of Tennyson's In Memoriam A.H.H. 
Whitman's attempt to write an elegiac spiritual autobiography, and in particular his decision to couch the autobiography in allegorical terms, can perhaps best be understood by viewing the poem as an example of what Harold Bloom, in his Anxiety of Influence, calls "creative revisionism." As Bloom explains it, every "strong poet" forms his own poetic identity through his awareness of, and reaction to, the work of other strong poets who have preceded him. The poet feels a profound ambivalence toward these precursors: "Poetic influence is the sense-amazing, agonizing, delighting-of other poets. . . . For the poet is condemned to learn his profoundest yearnings through an awareness of other selves. The poem is within him, yet he experiences the shame and splendor of being formed by poems - great poems - outside him." The poet responds to the presence of the precursor poets by writing a work that is a "creative revision" of their "great poems"; of the six types of revision that Bloom discusses, two seem particularly applicable to Whitman's "Out of the Cradle" (and perhaps to some of his other poems as well). First, there is climanen, or "swerve," which is a "corrective movement in [the new] poem, which implies that the precursor poem went accurately up to a certain point, but then should have swerved, precisely in the direction that the new poem moves." The second is the revision Bloom calls tessera, or "completion and antithesis": "a poet antithetically 'completes' his precursor by so reading the parent-poem as to retain its terms but to mean them in another sense, as though the precursor had failed to go far enough." 28 Viewing "Out of the Cradle" as the product-poem of one or the other of these two revisionary processes suggests that the line near the end of the poem's opening section,

Taking all hints to use them, but swiftly leaping beyond them, (1. 21)

is Whitman's conscious acknowledgment of the precursor poets whose "hints" have influenced him-perhaps especially in his own creation of an elegiac autobiography-as well as an expression of his belief that his own poem has "completed" or "corrected" the precursor poems by "leaping beyond them."

The ambivalence of the poet toward the precursor-what Bloom describes as "experiencing the shame and splendor of being formed by [great] poems ... outside him"-also offers an explanation for the curious way in which Whitman barely disguises his autobiographical statement. Whitman, seemingly caught between two desires in the poem, offers an extreme case of such ambivalence. On the one hand, he wants to acknowledge his indebtedness to the precursors, perhaps as a means of insuring that the reader will recognize his unique contribution within a well-established genre, the elegiac autobiography. On the other hand, he is afraid to reveal the precursors' influence, apparently because of the imagined effect that such an admission would 
have on his literary reputation as the uncontaminated American poet. Having once adopted this pose in 1855 in the Preface of Leaves of Grass, in the poems themselves, and in his anonymous self-reviews of that year, he could not easily abandon it. Yet as Stovall points out, he did at least partly discard the pose "in the poems written from 1859 on" 29 -which of course include "Out of the Cradle." The barely veiled allusions and echoes in the poem are strong pieces of evidence in support of Stovall's contention that Whitman partly discarded that pose in 1859 . The poem does indeed reveal a Whitman different from the 1855 "original American" through its acknowledgment of literary debt; however, the admission is offered in terms so private that it has until now remained undetected.

The image of the mockingbird is the single most important private symbol of the poem, one that, when traced to its sources, makes plain the autobiographical and allegorical nature of the poem. While it might plausibly be argued that Whitman's knowledge of the mockingbird came from his own observation of the bird on Long Island, there is compelling evidence that Whitman's primary source of information was not Nature, but three separate prose works. The first source, one which Florence Chace and Courtland White independently identified in the 1940s, is a book of ornithology, Birds of Long Island, which furnished Whitman with factual details about the mockingbird and its habitat in the poem (as well as with details about the awk, heron, and nighthawk which appear in other Whitman poems). ${ }^{30}$ The close verbal echoes and details from this book which appear within "Out of the Cradle" strongly suggest that it is indeed one of the mockingbird sources. For instance (to quote just one passage), the book states that

the nest is placed among the briars ... the eggs, from four to six in number, are light green, spotted with brown. . . . at times it frequents the dry sandy beaches in the immediate vicinity of the sea. ${ }^{31}$

Whitman renders this information in his poem as:

Up this seashore in some briars,

Two feather'd guests from Alabama, two together,

And their nest, and four light-green eggs spotted with brown. . . . (11. 25-27)

The second source of the mockingbird image is an 1849 critical article that Whitman heavily annotated, "Modern Poetry and Poets," a piece that Allen has identified as a possible source of some of the ideas behind Leaves of Grass. ${ }^{32}$ In this article, published in 1849, the term "mocking bird" is figuratively applied to poets who lack at least one of the necessary qualities that "the greatest poets" possess; these lesser poets are referred to in the article both as "plagiarists" and "imitators," "for they add nothing to that which they borrow." In a passage near the top of a column that Whitman has 
marked by writing "Shakespeare" above it, accompanying it with a handdrawn pointing finger directed downward toward the text, this reference to the mockingbird appears:

Shakespeare, it has been said, is but a voice. If so, it is a voice direct from nature's heart-and far indeed from the voice of a mocking bird. ${ }^{33}$

Shakespeare, in other words, is not, like the other authors discussed in the article, a mockingbird, an incomplete poet, but a "great poet."

Whitman adopts-or adapts-this mockingbird image for use in his poem, offering it not simply as a symbol of unnamed "lesser poets" who "add nothing to that which they borrow," but rather as a projection of his own poetic self,

O you singer solitary, singing by yourself, projecting me. . . (1. 150)

or more specifically, as a projection of himself as a solitary young man during a time when, on the beaches of Long Island, he read, learned of, and mimicked "the songs" of other poets - perhaps the same poets whose works he alludes to and borrows from in the poem. Whitman thus depicts multiple poetic identities in the poem: first, the mockingbird, whose elegiac lament is Whitman's own remembered cry of unresolved grief) over some still unidentified loss or event). Second, he depicts the boy, a passive "listener self" who learns from the bird's song - a "song" consisting of the works of other poets, and sung by the poet-apprentice Whitman:

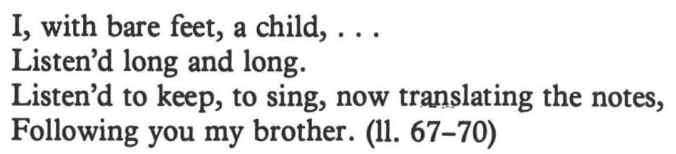

In passing, it should be noted that this depiction of the seashore as the site where the boy "listens" to the song of the bird helps to verify the autobiographical nature of the poem, since, as Bucke (among others) points out, during the late 1840s and early 1850s, Whitman "used to watch the English quarterlies and Blackwood, and when he found an article that suited him he would buy the number, perhaps second-hand, for a few cents, tear it out, and take it with him on his next sea beach excursion to digest. He followed the same practice with some books, especially anthologies." 34 It is this boyhood, or perhaps early manhood, act of reading and learning from other poets on the beach that Whitman allegorically depicts in his poem through the image of the boy "listening to" and "following" the mockingbird's song on "Paumanok's seashore."

The third and final poetic identity that Whitman depicts in the poem is that of the mature poet who emerges ("awakens") at poem's end: 
Now in a moment I know what I am for, I awake

...

A thousand warbling echoes have started to life within me, never to die. (11. 147-149)

But fuse the song of my dusky demon and brother, That he sang to me in the moonlight on Paumanok's gray beach,

With the thousand responsive songs at random,

My own songs awaked from that hour. ... (11. 175-178)

The emergence of his own "responsive songs," his "thousand warbling echoes," marks the point, for Whitman, of his true poetic awakening-the point when he progresses beyond the mockingbird's song, the period of his poetic apprenticeship.

The third source of the mockingbird image, an anthologized article named, appropriately enough, "The Mockingbird," suggests yet another reason why Whitman chose the symbol he called the "American mimic" in two other poems ${ }^{35}$ as an image of self in "Out of the Cradle." The article appears in Charles Knight's popular anthology, Half-Hours With the Best Authors, first published in 1849.36 Whitman was especially fond of this anthology: there are at least eighteen articles in the Trent Collection at Duke University that he clipped out of it, and Stovall, in his recent work, notes that nearly half of the book clippings in various Whitman collections are from this work. ${ }^{37}$ Whitman's interest in the details of the mockingbird's habits indicated by his earlier-discussed borrowings from Birds of Long Island suggests that the similar material of "The Mockingbird" article would have attracted and held his attention. However, what most strongly suggests the article as another source of the poem's central image is the fact that the description of the bird's song in it parallels in many respects Whitman's own method of composition in the poem (and perhaps in other poems as well). According to the article, the mockingbird's "genius" - one of Whitman's characteristic concerns - consists in his ability to imitate the songs of other birds, and to intersperse these songs within his own. This is precisely what Whitman has done in "Out of the Cradle"; whether the article did indeed furnish Whitman his own method of composition must remain a matter of conjecture, but the similarities between the mockingbird's song as described in the article and Whitman's own song are truly striking:

... the intelligence he displays in listening and laying up lessons from almost every species of the feathered creation within his hearing, is really surprising and marks the peculiarity of his genius.

And again: 
Neither is [the mockingbird's] strain altogether imitative. His own native notes, which are easily distinguishable by such as are well acquainted with those of our various song birds, are bold and full, and varied seemingly beyond all limits. ${ }^{38}$

Finally, the superiority of the bird's song is described both in Birds of Long Island and in "The Mockingbird" in terms which particularly would have attracted Whitman's attention, and which are in fact echoed in the poem. Birds of Long Island states that the mockingbird

$\ldots$ is the Nightingale of America, and according to those who have heard the native notes of both, its voice, both in variety and fullness, is superior to that of Europe's sweetest songster. Its power of imitation is so great, that this highly gifted bird runs over the varied notes of our songsters, and executes with so much skill, that it would seem as if Nature had so attuned its voice that it might exceed all of the feathered choir. ${ }^{39}$

"The Mockingbird" article continues in the same vein:

In force and sweetness of expression [the mockingbird] greatly improves upon [his originals.$^{40}$

These desciptions of the superiority of the mockingbird's song are clearly echoed in the lines from Whitman's poem which declare that his own song, his "reminiscence," "greatly improves upon" the precursors whose "hints" have influenced him:

Taking all hints to use them, but swiftly leaping

beyond them,

[I] A reminiscence sing.

\section{Monmouth College}

\section{NOTES}

1 Richard C. Harrison, "Walt Whitman and Shakespeare," PMLA, 44 (1929), 1201; Esther Shephard, Walt Whitman's Pose (New York: Harcourt, Brace \& Co., 1938), p. 236; Milton Hindus, "Literary Echoes in Whitman's 'Passage to India," Walt Whitman Review, 7 (September 1961), 52 .

2 Milton Hindus, "Whitman and Poe: A Note," Walt Whitman Review, 3 (December 1957), 5-6; Ned J. Davison, “'The Raven' and 'Out of the Cradle Endlessly Rocking,'” Poe Newsletter, 1 (April 1968), 5-6; Joseph M. DeFalco, "Whitman's Changes in 'Out of the Cradle' and Poe's 'Raven,'” Walt Whitman Review, 16 (March 1970), 22-27.

3 Thomas L. Brasher, "Whitman and Emma Willard's 'Rocked in the Cradle of the Deep," Walt Whitman Review, 4 (March 1958), 78.

4 Courtland Y. White, "A Whitman Ornithology," Cassinia, 35 (June 1945), 14; Florence M. Chace, "A Note on Whitman's Mockingbird in 'Out of the Cradle Endlessly Rocking," Modern Language Notes, 61(February 1946), 93-94. See also a brief reference to Whitman's use 
of Giraud in Sydney J. Krause, "Whitman's Yawping Bird as Comic Defense," Bulletin of The New York Public Library, 68 (1964), 353.

5 Esther Shephard, "An Inquiry Into Whitman's Method of Turning Prose Into Poetry," Modern Language Quarterly, 16 (March 1953), 54-56.

6 Walt Whitman, self-review printed in 1855 or 1856, as quoted in Herbert Bergman, "Whitman and Tennyson,"Studies in Philology, 51 (July 1954), 500.

7 Except for the reference to "An English and an American Poet," all of this information appears in Bergman, 493-499.

8 Whitman is known to have read In Memoriam prior to writing "Out of the Cradle." Two critics have identified Tennyson's poem as the source of lines in two other Whitman poems: Clarence Gohdes and Rollo G. Silver, eds., Faint Clews and Indirections (Durham: Duke University Press, 1949), p. 55, identify an echo from In Memoriam in an 1881 Whitman self-review; Freda A. Wise, on p. 27 of her 1932 University of Illinois M.A. Thesis, "A Study of the Reading Done by Walt Whitman," identifies another unmistakable echo from In Memoriam in Whitman's 1856 "To Think of Time."

9 Whitman is known to have read at least a good part of "The Princess" in 1857, just prior to his writing of "Out of the Cradle," as is indicated by his two hand-written comments in an article he owned, "Tennyson's Poems," which appeared in Blackwood's Edinburgh Magazine, 65 (April 1849), 453-468. On p. 461 of that article, which is now among the papers of the Trent Collection at Duke University, Whitman wrote, "This ["Ulysses"] redeems a hundred 'Princesses' and 'Mauds,' and shows the Great Master" [Whitman's italics]; on p. 467, he wrote "-I have read 'Maud'-It will not last long. - May '57."

10 The passage from "Poetry To-Day in America" appears in Maurice O. Johnson, "Walt Whitman as a Critic of Literature," The University of Nebraska Studies in Language, Literature and Criticism, 16 (1938), 53. Whitman's annotated copy of "Recollections of Poets Laureate. Wordsworth: Tennyson," American Whig Review, N.,S., 9 (June 1852), 515-524, is among the papers of the Trent Collection at Duke University. The annotated passage on Tennyson's "Sweetness" is on p. 521; on p. 523 Whitman has written, "Sept. 1855-Tennyson published 'Maud, \& other poems.' It is a love-story, rather tedious and affected, with some sweet passages."

11 Whitman finds "a latent charm" in a line from "The Passing of Arthur" (Tennyson's 1869 re-write of the 1842 "Morte D'Arthur"). See Walt Whitman, Complete Prose Works (Philadelphia: David McKay, 1892), pp. 402-403.

12 The Compact Edition of the Oxford English Dictionary (New York: Oxford University Press, 1973), 2:601, 604.

13 Floyd Stovall, The Foreground of Leaves of Grass (Charlottesville: University Press of Virginia, 1974), pp. 242-243, shows that Whitman admired Byron, and that as a contributor to the New Orleans Crescent in 1848, he knew Childe Harold's Pilgrimage well enough to casually quote from it.

14 Whitman is known to have read, and apparently to have appreciated, Shelley's "Skylark": the copy of the poem that he clipped out of Knight's Half-Hours With the Best Authors is among his private papers in the Trent Collection.

15 Almost every careful commentator of Whitman's career has noted the Biblical influence, and specific echoes of the Song of Songs and Job have been identified in other Whitman poems. See Gay W. Allen, "Biblical Analogies for Walt Whitman's Prosody," Revue Anglo-Américaine, 10 (1933), 313-314 and 490-507; and "Biblical Echoes in Whitman's Works," American Literature, 6 (1934), 302-315. Also see Milton Hindus, "Literary Echoes in Whitman's 'Passage to India,"” p. 52. 
16 Whitman's annotated copy of "Christopher Under Canvas," clipped from Blackwood's Edinburgh Magazine, 65 (June 1849), 763-766, is among the papers of the Trent Collection. The quoted passage appears on p. 764. Stovall, p. 238, notes that Whitman clipped out four articles dealing with The Prelude.

17 Walt Whitman, “The Question of Form," quoted in Esther Shephard, Walt Whitman's Pose (New York: Harcourt, Brace \& Co., 1938), p. 216.

18 Shakespeare's influence has frequently been noted: Whitman apparently read and re-read virtually all of Shakespeare's plays, and frequently recited whole passages of the plays from memory. See especially Harrison, pp. 1201-1220.

19 John Bartlett, Familiar Quotations, 14th ed. (Boston: Little, Brown and Co., 1968), pp. 702 and 236.

20 Whitman greatly admired Coleridge: he wrote several praise-worthy reviews of his works, including one on Biographia Literaria. See Stovall, pp. 110-111.

21 The Norton Antology of English Literature, 3rd ed. (New York: W. W. Norton \& Co., 1974), 2:326, n. 2. This bit of popular lore is also briefly discussed in Harold Bloom, The Visionary Company (Ithaca, N.Y.: Cornell University Press, 1971), p. 202.

22 Whitman is known to have admired Blake, and to have owned a copy of The Poems of Blake. See Horace Traubel, With Walt Whitman in Camden, Vol. 2 (New York: D. Appleton and Co., 1908), p. 99; see also Stovall, p. 49.

23 Shephard, for instance, who has probably done more work on Whitman's borrowings than any other critic, concludes on p. 236 and elsewhere that Whitman did borrow consciously.

24 Whitman, The Complete Writings of Walt Whitman (Boston: Small, Maynard \& Co., 1907), 6:190-191.

25 William S. Kennedy, Reminiscences of Walt Whitman, as quoted in Shephard, pp. 241242.

26 William H. Garrison, as quoted in Shephard, p. 241.

27 Gay W. Allen, The Solitary Singer (New York: Macmillan, 1955), p. 233.

28 Harold Bloom, The Anxiety of Influence: $A$ Theory of Poetry (New York: Oxford University Press, 1973); see especially pp. 14, 25-26, and 30. The italics are Bloom's.

29 Stovall, p. 138.

30 Chace, pp. 93-94; White, p. 14; see also Krause, p. 353.

31 J. P. Giraud, Jr., Birds of Long Island (New York: Wiley \& Putnam, 1844), p. 82-83.

32 The article, from the October 1849 American edition of The Edinburgh Review, is among the papers of the Trent Collection. See Allen, The Solitary Singer, pp. 131-134, for his views about the influence of this and several other Trent Collection articles on Whitman.

33 "Modern Poetry and Poets," p. 212.

34 Richard M. Bucke, M.D., Walt Whitman (Philadelphia: David McKay, 1883), p. 21. Stovall, p. 143, believes Bucke in this passage is speaking of Whitman's activities in "the late 1840 s and early 1850s."

35 In "Our Old Feuillage" and "O Magnet-South."

36 Stovall, p. 144, n. 12, says that the anthology was originally published in London, in 4 vols., in 1847-48; and that Whitman's copy was published in New York in 1849 by J. Wiley, in 6 vols. in 3 . All subsequent citations of the anthology in this paper are from an undated edition published in Philadelphia, in 6 vols, by Porter \& Coates. 
37 Stovall, p. 144. I have thus far been unable to find "The Mockingbird" among Whitman's collected articles, but his evidenced fondness for the anthology is virtual proof that he had read the piece.

38 Knight, p. 327.

39 Giraud, p. 83.

40 Knight, p. 327. 